\title{
A Comparative Assessment on Potable Water Supply In the Emerging Spread of Infectious Diseases In Urban Perspectives
}

\author{
Berame JS ${ }^{* 1,2}$, Albaciete $\mathrm{MF}^{1}$, Donatos $\mathrm{BD}^{1,3}$, Rimando RR ${ }^{1,4}$ \\ ${ }^{1}$ College of Education, Caraga State University, Philippines \\ ${ }^{2}$ De La Salle University, Manila, Philippines \\ ${ }^{3}$ Trinity College of Science and Technology, Misamis Oriental, Philippines \\ ${ }^{4}$ Butuan Medical Center, Butuan City, Philippines
}

Received: April 06, 2018; Published: April 16, 2018

*Corresponding author: Julie S Berame, College of Education, Graduate School, Caraga State University, Butuan City; De La Salle University, Taft, Manila, Philippines, Email: Janveel@yahoo.com

\begin{abstract}
The goal of this study is to assess the water condition of the two urban cities of Caraga Region XIII, namely: Butuan and Bayugan City and the extent of spread of emerging infectious diseases. The descriptive survey method was used in the study to investigate the problem. It is a fact-finding method by way of collecting data from the City Health Office, BCWD, CENRO, EMB of Butuan and Bayugan City and Department of Health (DOH). Results of physicochemical analysis of water were taken from Taguibo River Laboratoty in a non-conforming parameter with 16 color units exceeds the maximum level 10 color units. In the microbial analysis of water sample, there is less than 1.1 of coliforms and fetal coliforms observed and the remarks are negative that the water is safe. Its Colony Forming Unit (CFU) of microorganisms (bacteria molds and yeasts) is in the range of $47 \mathrm{cfu} / \mathrm{ml}$ where it passed the standard requirement for the water to declare as potable for drinking. The water supply of Butuan and Bayugan City have always monitored and tested in physical and chemical analysis. This water has an impact to the health of the people living in both cities. Emerging diseases such as simple diarrhea and intestinal worms were prevalent in both cities and attributed on the water process distributed per household.
\end{abstract}

Keywords: Comparative assessment; Infectious diseases; Water management; Local perspective; Potable water

\section{Introduction}

Currently, more than half of the world's population lives in urban areas and this will proportion will grow to almost $70 \%$ by 2050, according to a recent UN report, the largest increase will occur in Asia and Africa accounting for $90 \%$ of this growth. Urban life is generally characterized by better quality of life for the population in terms of access to health services, social and educational services. The other side of this reality, however the unplanned urbanization and migration lead to concentrations of the poorest and most vulnerable, making the urban environment itself a social determinant of health since, sanitation is a core precondition for development. In the beginning of 2000 , over $25 \%$ of all deaths in developing countries are caused by population lacked adequate sanitation. Approximately $80 \%$ of all diseases and $25 \%$ of all deaths in developing countries are caused by polluted water United Nations [1].
In many low-income areas, the modern city inhabitants suffer from ill health, lost income, inconvenience and indignity, particularly due to the lack of proper toilets. Studies have shown that investments in sustainable sanitation in developing regions brings a return in the range of 5US dollars to 46US dollars (depending on the intervention) for every 1 US dollar invested Hutton, Haller, and Bartram [2-4]. In order to address the most severe problems caused by poor sanitation

the focus needs to be in the fast growing cities of today. In the city of the future "sanitation" will be intermingled into other infrastructures and management processes in a way to completely different from what we see today. Productive sanitation system that produce e.g., renewable energy form biogas, or fertilizer (from the nutrients contained in excreta and waste water) will be fitted into 
general city planning in a mosaic of decentralize and centralized systems- using a range of technological components.

This paper is intended to serve as an "eye opener" for innovative approaches to water sanitation and is dedicated to illustrate what putting sustainable sanitation of addressing the rural-urban interface and the importance of avoiding negative downstream consequences, awareness of the threats of this urbanization since it possess a major public health outcome particularly in low and middle income settlers in Butuan and Bayugan City areas of which cities belong to Region XIII can become breeding grounds for emerging and re-emerging communicable diseases. The goal of this study is to analyze the water conditions of the two urban cities of CARAGA- Butuan and Bayugan City and to determine its water safety and assess the extent of the appearance of the emerging infectious diseases $[5,6]$.

\section{Methodology}

\section{Research Locale}

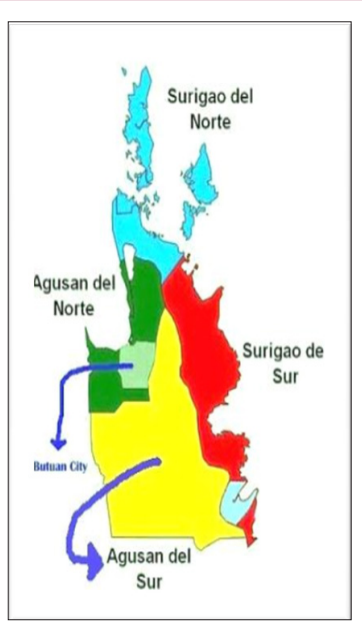

Figure 1: Map of Agusan del Norte and Agusan del Sur.

The study was conducted in Butuan and Bayugan City, the two big cities in Caraga Region XIII. Butuan City is the seat of government offices and the heart of commercial and industrial activities in Caraga Region. Butuan City has 86 barangays (27 Urban) and (59 Rural) known as First Class and Highly Urbanized City in Caraga Region. The population reached to 337,063 as of November 2017 according data taken from the Philippines Statistics Authority (PSA). Meanwhile, Bayugan City was formerly known as sitio of Barangay Maygatasan, Esperanza, which was located along the river. It covers 43 barangays and 29 rural areas (Figure 1).

\section{Research Design}

The descriptive survey method was used in the study in order to seek answers to the problems. The purpose of this study is to analyze the water conditions of the two urban cities of CARAGA Butuan and Bayugan City and determine its water safety and assess the extent of the appearance of the emerging infectious diseases It is a fact-finding method by way of collecting data from the City Health Office, BCWD, CENRO, EMB of Butuan and Bayugan City and from the Department of Health (DOH) [7]. The data gathered where incorporated and utilized as primary source answer the statement of the problem projected in this study. Survey was done through data gathering and initial interview to the offices mentioned above.

\section{Research Instrument}

The instruments used during the conduct of the study are the secondary data gathered from the city health office, water districts, DOH RO XIII Surveillance Unit and the local government of both Butuan and Bayugan City in 2017 [8]. The data were adopted as instrument for interview or survey. One of the test methods is mMultiple Tube Fermentation Technique in which MPN/100ml total Coliforms less than 1.1 or 0 less than 1.1 or 0 and MPN/100ml Fecal Coliforms less than 1.1 or 0 less than 1.12 or 0 means negative.

\section{Results and Discussion}

This presents the analyses and interpretation of data gathered from the tools of the study. The discussion focused on the areas, namely: Water assessment and the emerging infectious diseases. Table 1 shows the analysis of the water samples taken from Taguibo River and Filtration Plant of different parameters were used to test the sample from physical, odor, temperature, color apparent, turbidity and total suspended solids. In color apparent, water from Taguibo River exceeds the maximum level (maximum is 10 color units) which has 16 color units. (PNSDW, 2007)[9] Hence, it is the only non-conforming parameter in the analysis. In turbidity, water from Taguibo River has the highest unit of 2.03 but lower than the PNSDW maximum level which is 5 NTU.

Table 1: The physicochemical analysis of water in Butuan and Bayugan City.

\begin{tabular}{|c|c|c|c|c|c|}
\hline Sampling location & Taguibo River & \multicolumn{2}{|c|}{ Filration Plant, Taguibo } & \multirow[b]{2}{*}{ Product } & \multirow{2}{*}{$\begin{array}{c}\text { PNSDW Maximum } \\
\text { Level } \\
\begin{array}{c}\text { (mg/L) or } \\
\text { Characteristic }\end{array}\end{array}$} \\
\hline Sampling point & TASC DAM & Raw/Tap & Filtered & & \\
\hline Sampling date/time & June 15/ 9:26 am & June 28/9:15 am & \multicolumn{2}{|c|}{ June 28/9:25 am } & \\
\hline Parameters & & Results & & & \\
\hline \multicolumn{6}{|l|}{ Physical } \\
\hline Odor & Unobjectionable & unobjectionable & Unobjectionable & Unobjectionable & unobjectionable \\
\hline Temperature & 25.1 & 25.3 & 25.3 & 25.3 & deg. Celcius \\
\hline Color apparent & 16 & 6 & 1 & 3 & $10 /$ color Units \\
\hline Turbidity & 2.03 & 0.51 & 0.31 & 0.37 & 5 NTU \\
\hline Total Suspended Solids & 4 & 2 & 0 & 2 & _mg/L \\
\hline
\end{tabular}




\begin{tabular}{|c|c|c|c|c|c|}
\hline Chemical & & & & & \\
\hline $\mathrm{pH}$ & 7.79 & 7.84 & 8.03 & 7.96 & $6.5=8.5$ \\
\hline Salinity & 0.1 & 0.1 & 0.1 & 0.1 & _ppt \\
\hline Specific conductance & 233 & 229 & 234 & 240 & _us/cm \\
\hline Total dissolved solids & 111.6 & 109.5 & 0.04 & 114.9 & $\begin{array}{l}\text { 500mg/L undergo } \\
\text { RO/Distillation }\end{array}$ \\
\hline Iron & 0.02 & 0.01 & 0.01 & 0.02 & $0.4 \mathrm{mg} / \mathrm{L}$ \\
\hline Manganese & 0.03 & 0.02 & 7.7 & 4.1 & $50 \mathrm{mg} / \mathrm{L}$ \\
\hline Nitrate & 6 & 5.2 & 4 & 4 & $250 \mathrm{mg} / \mathrm{L}$ \\
\hline Sulfate & 6 & 3 & 14.18 & 15.6 & $250 \mathrm{mg} / \mathrm{L}$ \\
\hline Chloride & 7.8 & 14.18 & 0.05 & 0.04 & $1.0 \mathrm{mg} / \mathrm{L}$ \\
\hline Copper & 0.05 & 0.02 & 0.04 & 0.05 & $1.0 \mathrm{mg} / \mathrm{L}$ \\
\hline Fluoride & 0.19 & 0.06 & 98.6 & 96.43 & _mg/L \\
\hline Alkalinity, total & 100.78 & 94.26 & 4.35 & 3.63 & _mg/L \\
\hline Alkalinity, php & 4.35 & 5.08 & 109.68 & 108.79 & _mg/L \\
\hline Bicarbonates & 112.34 & 6.1 & 5.22 & 4.36 & _mg/L \\
\hline Total hardness & 5.22 & 111 & 111 & 111 & $300 \mathrm{mg} / \mathrm{L}$ \\
\hline $\mathrm{Mg}$ (as CaCO3 & 28 & 26 & 26 & 26 & $\_\mathrm{mg} / \mathrm{L}$ \\
\hline Calcium (asCaCO3) & 86 & 85 & 85 & 85 & _mg/L \\
\hline Parameters & COLOR & NONE & NONE & NONE & \\
\hline
\end{tabular}

For the chemical analysis, its salinity, specific conductance, total dissolved solids and seventeen different chemical compounds that were chosen if it is positive in the water sample taken (PNSDW) $[9,10]$. The different chemical compounds are present in all water samples but its volume is lower than the maximum level. Bicarbonates have the highest volume level in $\mathrm{mg} / \mathrm{L}, 112.34,102.6$, 109.68 and 108.79 respectively among all the four water samples and all compounds present, while iron has the lowest volume 0.02 ,
0.01, 0.04 and $0.02 \mathrm{in} \mathrm{mg} / \mathrm{L}$. For the water hardness, the four water samples are moderately hard because their volume is between 60 $120 \mathrm{mg} / \mathrm{L}$. Water containing calcium carbonate at concentrations below $60 \mathrm{mg} / \mathrm{l}$ is generally considered as soft; $60-120 \mathrm{mg} / \mathrm{l}$, moderately hard; $120-180 \mathrm{mg} / \mathrm{l}$, hard; and more than $180 \mathrm{mg} / \mathrm{l}$, very hard McGowan [11]. In terms of $\mathrm{pH}$, salinity and specific conductance, their volume is quite lower than the maximum level WHO [12].

Table 2: The test report of microbiological analysis of drinking water in Sendrjas Green Village, Bayugan City.

\begin{tabular}{|c|c|c|c|c|}
\hline \multicolumn{2}{|c|}{} & \multicolumn{2}{|c|}{ Result of Analysis } & Remarks \\
\hline Laboratory No. & HPC CFU/ml & $\begin{array}{c}\text { Total coliforms } \\
\text { MPN/100ml }\end{array}$ & $\begin{array}{c}\text { Fetal coliforms } \\
\text { MPN/100ml }\end{array}$ & Negative \\
\hline 6921 & $47 \mathrm{cfu} / \mathrm{ml}$ & $<1.1$ & $<1.1$ & Negative \\
\hline Values for & $<500$ & $<1.1$ & $<1.1$ & Negative \\
\hline Values for & $<200$ & $<1.1$ & $<1.1$ & \\
\hline
\end{tabular}

Table 2 shows the heterotrophic plate count (HPC) per mL of the sample taken for test and analysis and in the range of $47 \mathrm{cfu} / \mathrm{ml}$ or (Colony Forming Unit) of microorganisms (bacteria, molds and yeasts) that use organic carbon sources to grow and can be found in all types of water reached to a scale where it passed the standard requirement for the water to declared as potable for drinking. The result means that in every $100 \mathrm{ml}$. water sample tested, they only observed 1.1 of coliforms and fetal coliforms. In this case, the remarks are negative where the water is safe for drinking. The standard of it must be "Total and Fecal Coliforms: < 1.1 MPN (Most Probable Number) per 100mL and for Heterotrophic Count (HPC) < 500 CFU (Colony Forming Units) per $100 \mathrm{~mL}$ " according to "PNSDW*Limits AO 2007-0012 [13]. The analysis shows that there were $47 \mathrm{HPC}$ or $\mathrm{CFU} / \mathrm{ml}$ microbes found, therefore it is safe for water drinking because the standard of PNSDW is "O - 3ppm detection of bacteria or permissible level of CFU $/ 100 \mathrm{ml}$. As for the values of $<500$ and $<200 \mathrm{in} \mathrm{CFU/mL,} \mathrm{it} \mathrm{is} \mathrm{also} \mathrm{safe} \mathrm{for} \mathrm{swimming,} \mathrm{boating} \mathrm{and}$ fishing activities since the permissible level for $\mathrm{CFU} / 100 \mathrm{ml}$ range from $<200$ to $<1,000$ (PNSDW) [9].

Table 3 is a representation of BCWD annual report wherein they have served to 37,703 connections which is then multiplied with the average number of individuals per service connection which is seven resulting to 263,921 service population. There were 46 minimum samples required for bacteriological analysis every month but BCWD established 55 sampling points for bacteriological analysis and then later changed to 56 by the month of May 2015, adding Pump Station 17. As of December 2015, BCWD concessionaires grew to 41,024 for an equivalent 
population of 287, 168. Bacteriological analysis of water was conducted for fecal detection and identifies, quantify and evaluate pathogenic organisms associated with waterborne diseases. It is intended to minimize risk and therefore prevent deleterious health repercussions that result from lifelong exposure to these impurities through consumption of water (PNSDW) [9] (Table 4). In all surveyed households particularly in Butuan and Bayugan City, there were cases for the various ailments mentioned. Based on the data in Table 1, simple diarrhea is the most prevalent disease in both cities followed by intestinal worms. There is no incidence of cholera in Agusan Del Sur while it prevails in Butuan. Whereas in terms of typhoid fever, Agusan Del Sur has a higher percentage of $6 \%$ compare to Butuan City with 3\%. Bloody diarrhea and skin diseases' percentages are quite higher in Butuan City, 10\% to 14\% respectively than Agusan del Sur, with $6 \%$ to $10 \%$. Between the two focused cities, Butuan City has the highest incidence rate $92 \%$ of water borne diseases. RESU DOH RO XIII [14].

Table 3: Minimum Frequency of sampling for drinking-water supply systems for Microbiological examination.

\begin{tabular}{|c|c|c|}
\hline Source and Mode of Supply & Population served & Minimum frequency of sampling \\
\hline Level I & $90-150$ & Once in three (3) months \\
\hline Level II & 600 & Once in two (2 months \\
\hline Level III & Less than 5,000 & 1 sample monthly \\
\hline & $5,000-100,000$ & 1 sample per 5,000 population monthly \\
\hline & More than 100,000 & 20 samples and additional one (1) sample per 10,000 populations monthly. \\
\hline
\end{tabular}

Source: Based on the Philippine National Standards for Drinking Water 2007.

Table 4: Incidence of water borne diseases in Butuan and Bayugan City from 2012 up to present.

\begin{tabular}{|c|c|c|c|c|c|c|c|c|c|}
\hline Community & $\#$ / \% & $\begin{array}{c}\text { Simple } \\
\text { Diarrhea }\end{array}$ & $\begin{array}{c}\text { Bloody } \\
\text { Diarrhea }\end{array}$ & Cholera & $\begin{array}{l}\text { Typhoid } \\
\text { Fever }\end{array}$ & $\begin{array}{c}\text { Skin } \\
\text { Problems }\end{array}$ & $\begin{array}{c}\text { Intestinal } \\
\text { Worms }\end{array}$ & Total & \\
\hline & & & & & & & & Freq \% & Total \\
\hline \multirow[t]{2}{*}{ Bayugan City } & \# of reported cases & 22 & 4 & 0 & 4 & 11 & 9 & 50 & $12 \%$ \\
\hline & $\%$ & $31 \%$ & $6 \%$ & $0 \%$ & $6 \%$ & $10 \%$ & $13 \%$ & $66 \%$ & \\
\hline \multirow[t]{2}{*}{ Butuan City } & \# of reported cases & 29 & 9 & 4 & 3 & 14 & 27 & 86 & $16 \%$ \\
\hline & $\%$ & $32 \%$ & $10 \%$ & $4 \%$ & $3 \%$ & $14 \%$ & $29 \%$ & $92 \%$ & \\
\hline
\end{tabular}

\section{Conclusion}

The water supply distributed by two major cities, Butuan and Bayugan City has always monitored in physicochemical analysis. It has any impact on how water sources are processed, stored and used to the health of the people in the community living in Butuan and Bayugan City. Emerging diseases such as diarrhea, cholera, typhoid fever, skin diseases and intestinal worms, attributed to the water supply especially if it has not processed properly or there are abnormalities during the distribution [15]. It has significant relationship to the emerging of infectious diseases and how it is process and consumed by the people. In all surveyed households particularly in Butuan and Bayugan City, there were cases for the various ailments mentioned. Based on the data in Table 1, simple diarrhea is the most prevalent disease in both cities followed by intestinal worms. There is no incidence of cholera in Agusan Del Sur while it prevails in Butuan. Whereas in terms of typhoid fever, Agusan Del Sur has a higher percentage of $6 \%$ compare to Butuan City with $3 \%$. Bloody diarrhea and skin diseases' percentages are quite higher in Butuan City, 10\% to 14\% respectively than Agusan Del Sur, with $6 \%$ to $10 \%$. Between the two focused cities, Butuan City has the highest incidence rate $92 \%$ of water borne diseases. RESU DOH RO XIII, $[14,16]$.

\section{Recommendation}

a) For the Local Government (City Health, Water District, CENRO), they must provide or allocate budget for funding basic facilities. With regards to water supply, since most of the residents in the city rely on public water supply (by the Municipality), it is recommended to make the source of water supply for Butuan City sufficient for daily use at homes, offices, business establishments and schools during the long hours of cut off time of water supply.

b) Further studies should be made by future researchers to authenticate the findings of this study. Collect further information and primary data by doing another physicochemical analysis of water.

c) Lastly, this study recommends conducting massive campaign and seminar/lecture to the people in the community for the awareness of different emerging and re-emerging infectious diseases that might be the result of water supply and to other health related concerns of our bodies.

\section{Acknowledgement}

We express our gratefulness to the Almighty Father, Department of Health (DOH) and those who had extended their help in contributing to this research paper.

\section{References}

1. Fisher NM, Pendergast DR (1997) Reduced muscle function in patients with osteoarthritis. Scand J Rehabil Med 29(4): 213-221.

2. Jadelis K, Miller ME, Ettinger WH Jr, Messier SP (2001) Strength, balance, and the modifying effects of obesity and knee pain: results from the 
Observational Arthritis Study in Seniors (oasis). J Am Geriatr Soc. 49(7): 884-891.

3. Martin JA, Buckwalter JA (2002) Aging, articular cartilage chondrocyte senescence and osteoarthritis. Biogerontology 3(5): 257-264.

4. Bade MJ, Kohrt WM, Stevens Lapsley JE (2010) Outcomes before and after total knee arthroplasty compared to healthy adults. J Orthop Sports Phys Ther 40(9): 559-567.

5. Cho SD, Hwang CH (2013) Improved single-limb balance after total knee arthroplasty. Knee Surg Sports TraumatolArthrosc 21(12): 2744-2750.

6. Rasch A, Dalen N, Berg HE (2010) Muscle strength, gait, and balance in 20 patients with hip osteoarthritis followed for 2 years after THA. ActaOrthop 81(2): 183-188.

7. Pozzi F, Snyder Mackler L, Zeni J (2013) Physical exercise after knee arthroplasty: a systematic review of controlled trials. Eur J Phys Rehabil Med 49(6): 877-892.

8. Levinger P, Menz HB, Morrow AD, Wee E, Feller JA, et al. (2012) Lower limb proprioception deficits persist following knee replacement surgery despite improvements in knee extension strength. Knee Surg Sports TraumatolArthrosc 20(6): 1097-1103.

9. Swinkels A, Newman JH, Allain TJ (2009) A prospective observational study of falling before and after knee replacement surgery. Age Ageing 38(2): 175-181.

10. Matsumoto H, Okuno M, Nakamura T, Yamamoto K, Hagino H (2012) Fall incidence and risk factors in patients after total knee arthroplasty. Arch Orthop Trauma Surg 132(4): 555-563.

11. Levinger P, Wee E, Margelis S, Menz HB, Bartlett JR, et al. (2017) Preoperative predictors of post-operative falls in people undergoing total hip and knee replacement surgery: a prospective study. Arch Orthop Trauma Surg 137(8): 1025-1033.

12. Tsonga T, Michalopoulou M, Kapetanakis S, Giovannopoulou E, Malliou P, et al. (2016) Reduction of Falls and Factors Affecting Falls a Year After Total Knee Arthroplasty in Elderly Patients with Severe Knee Osteoarthritis. Open Orthop J 10: 522-531.

13. Tinetti ME, Speechley M, Ginter SF (1988) Risk factors for falls among elderly persons living in the community. N Engl J Med 319(26):17011707.

14. Nevitt MC, Cummings SR, Hudes ES (1991) Risk factors for injurious falls: a prospective study. J Gerontol 46(5): M164-170.

15. Campbell AJ, Spears GF, Borrie MJ (1990) Examination by logistic regression modelling of the variables which increase the relative risk of elderly women falling compared to elderly men. J ClinEpidemiol 43(12): 1415-1420.

16. Robbins AS, Rubenstein LZ, Josephson KR, Schulman BL, Osterweil D, et al. (1989) Predictors of falls among elderly people. Results of two population-based studies. Arch Intern Med 149(7): 1628-1633.

17. (2001) American Academy of Orthopedic Surgeons panel of falls prevention. Guideline for the prevention of falls in older persons. J Am GeriatrSoc 49(5): 664-672.

18. Maki BE, Mcllroy WE (1996) Postural control in the older adult. Clin Geriatr Med 12(4): 635-658.

19. Friedman SM, Munoz B, West SK, Rubin GS, Fried LP (2002) Falls and fear of falling: which comes first? A longitudinal prediction model suggests strategies for primary and secondary prevention. J Am GeriatrSoc 50(8): 1329-1335.

20. Kemp G, Crossley KM, Wrigley TV, Metcalf BR, Hinman RS (2008) Reducing joint loading in medial knee osteoarthritis: shoes and canes. Arthritis Rheum 59(5): 609-614.

21. Li K, Ackland DC, Mc Clelland JA, Webster KE, Feller JA, et al. (2013) Trunk muscle action compensates for reduced quadriceps force during walking after total knee arthroplasty. Gait Posture 38(1): 79-85.

22. Berman AT, Quinn RH, Zarro VJ (1991) Quantitative gait analysis in unilateral and bilateral total hip replacements. Arch Phys Med Rehabil 72(3): 190-194.

23. Shakoor N, Block JA, Shott S, Case JP (2002) Nonrandom evolution of end-stage osteoarthritis of the lower limbs. Arthritis Rheum 46(12): 3185-3189.

24. Chang QZ, Sohmiya M, Wada N, Tazawa M, Sato N, etal. (2011) Alternation of trunk movement after arthroplasty in patients with osteoarthritis of the knee. J Orthop Sci 16(4): 382-388.

25. Niki Y, Nagura T, Nagai K, Kobayashi S, Harato K (2017) Kinematically aligned total knee arthroplasty reduces knee adduction moment more than mechanically aligned total knee arthroplasty. Knee Surg Sports Traumatol Arthrosc.

26. Molina Rueda F, Alguacil Diego IM, Cuesta Gómez A, Iglesias Giménez J, Martín Vivaldi A, et al. (2014) Thorax, pelvis and hip pattern in the frontal plane during walking in unilateral transtibial amputees: biomechanical analysis. Braz J Phys Ther 18(3): 252-258.

27. Chan GN, Smith AW, Kirtley C, Tsang WW (2005) Changes in knee moments with contralateral versus ipsilateral cane usage in females with knee osteoarthritis. Clin Biomech (Bristol, Avon) 20(4): 396-404.

28. Alnahdi AH, Zeni JA, Snyder Mackler L (2011) Gait after unilateral total knee arthroplasty: frontal plane analysis. J Orthop Res 29(5): 647-652.

29. Hatfield GL, Hubley Kozey CL, Astephen Wilson JL, Dunbar MJ (2011) The effect of total knee arthroplasty on knee joint kinematics and kinetics during gait. J Arthroplasty 26(2): 309-317.

30. Mandeville D, Osternig LR, Lantz BA, Mohler CG, Chou LS (2008) The effect of total knee replacement on the knee varus angle and moment during walking and stair ascent. Clin Biomech 23(8): 1053-1058.

31. Orishimo KF, Kremenic IJ, Deshmukh AJ, Nicholas SJ, Rodlriguez JA (2012) Does total knee arthroplasty change frontal plane knee biomechanics during gait? Clin Orthop Relat Res 470(4): 1171-1176.

32. Hilding MB, Lanshammar H, Ryd L (1996) Knee joint loading and tibial component loosening. RSA and gait analysis in 45 osteoarthritic patients before and after TKA. J Bone Joint Surg Br 78(1): 66-73.

33. Komnik I, Weiss S, Fantini Pagani CH, Potthast W (2015) Motion analysis of patients after knee arthroplasty during activities of daily living-a systematic review. Gait Posture 41(2): 370-377.

34. Matsumoto $\mathrm{H}$, Okuno $\mathrm{M}$, Nakamura T, Yamamoto $\mathrm{K}$, Osaki $\mathrm{M}$, et al. (2014) Incidence and risk factors for falling in patients after total knee arthroplasty compared to healthy elderly individuals. Yonago Acta Med 57(4): 137-145.

35. Grabiner MD, Donovan S, Bareither ML, Marone JR, Hamstra Wright K, et al. (2008) Trunk kinematics and fall risk of older adults: translating biomechanical results to the clinic. J Electromyogr Kinesiol 18(2): 197204. 


\section{(C) (i) This work is licensed under Creative}

Submission Link: https://biomedres.us/submit-manuscript.php

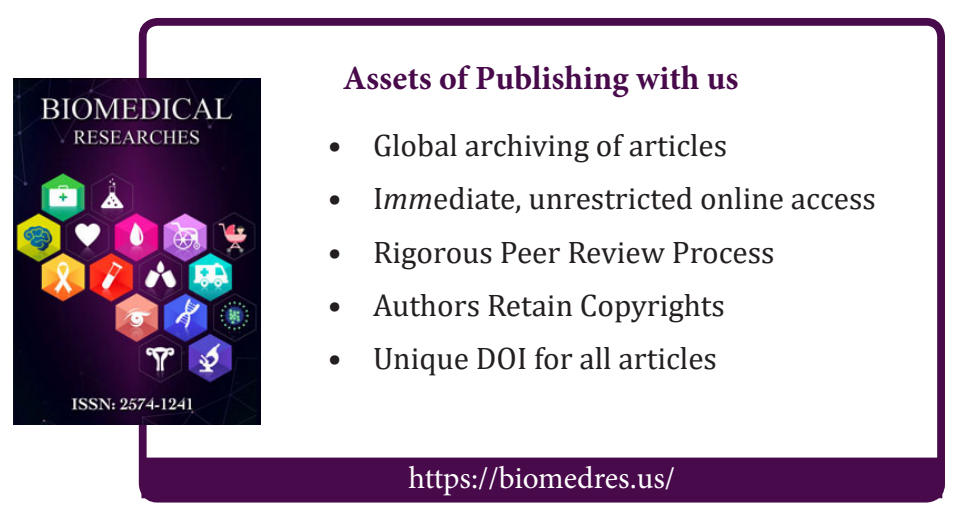

